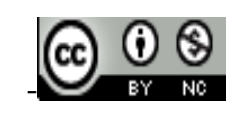

Journal of Education, Teaching, and Learning is licensed under

A Creative Commons Attribution-Non Commercial 4.0 International License.

\title{
CRITICAL Discourse ANALYSIS TOWARDS AUTHORITY IDEOLOGY "CASE OF MEGA CORRUPTION E-KTP (ELECTRONIC ID CARD) " IN TEMPO MAgAZINE
}

\author{
Martono $^{1)}$, Sri Mulyani ${ }^{2)}$ \\ 1) Universitas Tanjungpura, Pontianak, Indonesia \\ E-mail: martono_fkipuntan@yahoo.co.id \\ 2) Universitas Tanjungpura, Pontianak, Indonesia \\ E-mail:Srimulyani.stkip@gmail.com
}

\begin{abstract}
The ideology that is reflected in the discourse of Tempo Magazine in 2017 'the case of Mega Corruption e-KTP is seen from the text structure which includes the macrostructure. The global meanings studied are interrelated. The data obtained by journalists are used to discuss the topic of e-KTP case. "Fireball Corruption KTP". Superstructure discourse discussed based on the introduction, the contents, the cover, but not found conclusions. The preliminary section described has always supported the title of the discourse. The content section is the focus of journalist's study on e-KTP corruption issues. The closing section used by journalists always gives a settlement of the news presented. The microstructure of the discourse uses effective, straightforward and diction sentences. Ideology is seen from social cognition. There is a linkage of texts that journalists describe with the community. All perceptions and actions, and ultimately the production and interpretation of this discourse are based on the mental representation of every event that takes place. Events are presented based on a lot of evidence and believed to be true. Ideology is seen from the social context that includes the practice of power and access to affect the discourse. The practice of power in the discourse on the topic of mega corruption is related to the members of the People's Legislative Assembly and the Chief Judge of the Court. The Chief Justice used his power to reprimand the accused. Judging from the access that influences discourse then found a character who can use and or influence the discourse.
\end{abstract}

Keywords: Critical Discourse; Ideology; e-KTP Corruption

\section{INTRODUCTION}

Language is the medium of communication. The form of language can be written or spoken. The language used by a speaker or writer is used to pour ideas or ideas. A person speaking or writing is not interpreted as he writes or speaks for himself but to communicate with others. The idea is the result of the speaker's or writer's thinking. The idea serves to influence, persuade, argue, disprove and so on. According to Samsuri, 1994: 69) each speaker performs a pronunciation act that is certainly associated with a concept.

Language is not only a means to communicate, but there are forces in the language. That power is usually called ideology. The ideology of the speaker or author is very influential on the listener or reader. Want to be taken to where the listener or reader is strongly influenced by the desire of the speaker or author. According to Fairclough (1992: 5), changes in language practice are closely related to changes occurring in social relationships and with social identity changes (in this case, both the professional social identity and the social identity of their clients).

According to Eriyanto (2001) language is a battleground of various groups and social classes trying to instill confidence and understanding. The ideological effect of a discursive formation that positions a person as a subject in a particular social situation. Language in a critical view is understood as a representation that plays a role in shaping certain 
subjects, themes of particular discourse, as well as strategies within them. Therefore, discourse analysis is used to dismantle the power that exists in every language process: what constraints are allowed to be discourse, perspective to be used, what topics are discussed.

According to Thomson (1984), the language is not just a means of communication or knowledge, but also as a tool of power. One seeks not only to be understood but also to be trusted, obeyed, respected, differentiated. The complete definition of competence is the right to speak, namely the right to legitimate language, authorized language, language of authority. Competence implies the power to impose acceptance.

According to Darma (2009: 10) text in the media is the result of the process of media discourse. In the process, the values, ideology, and interests of the media participated. It shows that the media is "not neutral" when constructing social reality. According to Tuchman (in Darma (2009) the media involves their perspective and perspective in interpreting social reality, choosing them to determine the aspects that are highlighted or eliminated, to determine the structure of the news according to their will, from which point the event is highlighted, which of the events are preceded or forgotten, which parts of the news are highlighted or omitted and who are interviewed to be sources of news and etc. The news is not a representation of events solely, but in it also contains the values of media institutions that make it.

The critical view of the news is the result of a discourse struggle between the various forces in society that always involve the views and ideology of journalists or the media. How reality is made news depends on how the fight takes place, which is generally won by dominant forces in society. (Eriyanto, 2001).

This study examines the language used in the media especially Tempo Magazine. Tempo Magazine reported many related to the authorities. By using a language with a choice of good words. Tempo magazine became the magazine of choice to read. This research sees the prejudice or opposition of Tempo Magazine against the authorities or the weak. Discourse topics related to "Against the Ideology of Rulers" Fires of Corruption KTP Corruption "in Tempo Magazine" seen from the structure of the text, social cognition, and social context.

To examine this study, researchers used critical discourse analysis. Why use critical discourse analysis? The analysis of critical discourse to learn about the dominance of an ideology and injustice is run and operated through discourse. Fairclough (1998) finds that critical discourse analysis sees discourse as a form and social practice. Describing discourse as a social practice leads to a dialectical relationship between a particular discursive event with the institutional situation, and the social structure that shapes it. Discourse practice presents an ideological effect. Discourse is seen not only from the structure of discourse but rather examines how discourse is produced.

To analyze the existing discourse texts in Tempo Magazine using van Dijk theory focusing on three focuses: first, the structure of the text, social cognition, and social context. The focus of the text is to examine how text structures and discourse strategies are used to assert a particular theme. The second focus is social cognition studied the process of producing a news text that involves the individual's cognition of the journalist. The third focus is the social context of learning the building of discourse that develops in society will be a problem. This analysis links textual analysis - which focuses on the text - toward a comprehensive analysis of how the text is produced, both in relation to individual journalists and from society (see Eriyanto, 2001; Darma, 2009).

The Nature of Language in Critical Discourse Analysis

The man has the advantage of other creatures created by God. The advantages include the ability to think and have the ability to communicate. Thinking is used to develop human self and language is a tool for communication with fellow human beings. The form of language can be spoken or written. According to Spradley, (1997: 23) language has the ability to state more than what is conveyed. Language is more than a means of communicating reality; language is a tool for breaking reality.

Languages spoken or written are inseparable from speaker or author's intent with social facts. According to Titscher (2009: 241) on the basis of the complex relationship between language and social facts, the effects of ideology are often unclear and hidden in the use of language as well as the influence of power reactions. In the discourse, expressed ideology and structure of practice are generally not analyzed or asked.

According to Fawler et al. (in Ariyanto, 2010: 164) the language used by the media is not something that is neutral but has certain aspect or ideological value. The important issue here is how the reality is conceived by the media. That reality can mean how the events and actors involved in the event are represented in the preaching through the language used. Language as a representation of reality can be changed and completely different from the actual reality.

Language has the power to influence others. According to Gadamer (in Poespoprodjo, 1987: 114) language is not a fixture that complements a man in this world. In and on human language has the world. The existence of the world is laid in the language.

According to Eriyanto (2001: 6) language in critical view is understood as a representation that plays a role in shaping certain subjects, themes of 
particular discourse, as well as strategies in it. Therefore, discourse analysis is used to dismantle the power that exists in every language process: what constraints are allowed to be the discourse, the perspectives to be used, what topics are discussed. According to Hikam (in Eriyanto, 2001) discourse to see the language is always involved in power relations, especially in the formation of subjects, and various acts of representation contained in the community.

The language used in the media has a meaning. Meaning it is the ideology of the author or speaker. What is the role of discourse within the framework of ideology? Ideology is primarily intended to regulate the problem of the actions and practices of individuals or members of a group. Ideology enables members of a group to act in the same situation, connect their problems, and contribute in the form of solidarity and cohesion within the group.

The Nature of Critical Discourse Analysis

Discourse is to discuss the language and it should be in a unified set of user situations. Here, the meaning of a language lies in a series of contexts and situations (Sobur, 2002: 10). Discourse discussion is basically a discussion of the relationship between the contexts contained in the text. Pembahsan it aims to explain the relationship between the sentence or between speech that forms the discourse.

Dijk (in Darma, 2009: 51) finds that critical discourse analysis is used to analyze critical discourses, including politics, race, gender, social class, hegemony, and so on. The analyzed language does not describe only the language aspect but also relates it to the context. The context, in this case, means the language is used for certain purposes including the practice of power in the community.

According to Jorgensen and Louise (2010: 120), the critical discourse analysis is "critical" the point is that this analysis aims to reveal the role of discourse practice in the preservation of the social world, including social relations involving disproportionate power relations. Therefore, the aim is to be able to contribute to social change along the lines of power relations in the communications process and society in general.

Habermas (in Darma, 2009: 53) critical discourse analysis aims to help analyze and understand social problems in the relation to ideology and power. In addition to developing the ideological assumptions contained behind the words in the text or speech in various forms of power. According to Darma (2009: 58) some of the main ideas about the critical study of language are (1) discourse shaped by society, (2) discourse helps to shape and change knowledge and objects, social relations, and social identity, (3) discourse formed by power relations and related to ideology, (4) the formation of the discourse of man marks of power struggles, (5) discourse to examine how society and discourse form one another.

According to Thomson (1990: 68), ideology is a system of representation that seeks to preserve the existence of dominant class relation through individuals who are always oriented in the past rather than the future, or on images and ideas that hide class relations and seek to avoid the collective pursuit of social change. The similar opinion expressed by Darma (2009: 56) ideology is a value system or idea owned by a particular group or layer of society, including processes that are common in the production of meaning and ideas.

The purpose of critical discourse analysis is to explain the linguistic dimension of social and cultural phenomena and the process of change in modernity. In critical discourse analysis (as in general discourse analysis) there is a tendency to analyze images as if they were linguistic texts. There are exceptions of social semiotics (see Jorgensen and Louise, 2010).

The basis of critical discourse analysis is interpretation since discourse analysis is part of an interpretive method that relies on interpretation and interpretation of the researcher. Therefore, in the process of working, discourse analysis does not require coding sheets that take some items or speeches from certain concepts. Through critical discourse analysis not only know how the content of the news text, but also how the message is delivered. Through words, phrases, sentences, metaphors what kind of news is delivered. By looking at how these linguistic structures are structured, discourse analysis can more see the hidden meaning of a text.

Model analysis of Teun A. Van Dijk

According to van Dijk (in Eriyanto, 2001: 221) discourse research is not enough to be based solely on the analysis of the text alone since the text is only the result of a production practice that must also be observed. It should also be seen how a text is produced so that we obtain a knowledge of why the text can be that way? Van Dijk's analysis links textual analysis that focuses on the text toward a comprehensive analysis of how the text is produced, both in relation to individual journalists and from society.

Van Dijk analysis model there are three components that build the discourse. The three components are (1) text, (2) social cognition, (3) social context. The core of Van Dijk's analysis is to combine the three dimensions of the discourse into a single unit of analysis. In the dimensions of the text, what is examined is how the structure of the text and discourse strategies are used to affirm a particular theme. In social cognition is studied the process of producing a news text that involves the individual's cognition of the journalist. The third component examines the building of discourse that develops in society about a problem. 
Text written by journalists has a purpose. According to Eriyanto, (2001: 222), the text is not something that comes from the sky, nor is it an independent vacuum. The text, however, is formed in a practice of discourse, a practice of discourse. If there is a text that marginalizes a woman, it does not mean the text is a vacuum, nor something coming from the sky. The text comes from parts of representations that describe patriarchal society. If studied then, the discourse is divided into two, namely a micro text that represents marginalization of women in the news discourse, and a large element of the patriarchal social structure of society.

The text consists of several structures/levels in which each part supports each other. According to Van Dijk (in Eriyanto, 2001: 226), there are three parts. First, the macrostructure. This is a global/general meaning of a text that can be observed by looking at a topic or theme put forward in a story. Second, the superstructure. It is a discourse structure that deals with the framework of a text, how parts of the text are composed of the story as a whole. Third, microstructure is a discourse meaning that can be observed from a small part of a text ie word, sentence, proposition, clause, paraphrase, and picture.

The social connections put forward by Van Dijk to bridge those associated with a large element of social structure with a micro-discourse element with a dimension called social cognition. Social cognition has two meanings. On the one hand, it shows how the process of text is produced by journalists/media, on the other hand, it describes how patriarchal society's values are spread and absorbed by the cognition of journalists, and eventually used it to make news texts (Eriyanto 2001: 222). Social cognition is a dimension to explain how a text is produced by an individual/group of text-makers. How to see a social reality that gave birth to a particular text.

\section{MethodolOGY}

\section{A. Research Methods}

The method used in this research plan is descriptive method. The use of descriptive methods is useful for giving a true picture of something. This method can be interpreted as a problem-solving procedure that is investigated by describing or describing the current state of the subject or object of research on the basis of visible or actual facts. Based on the theory it can be concluded that this method is most effective use in this research because researcher wants to get real picture about ideology which is reflected in discourse of Tempo magazine by 2017 with focus of study of text structure, social connection, and social context.

\section{B. Form of Research}

The design of this research is qualitative. The form of research is a written word written by journalists in Tempo Magazine. The design of qualitative research design is a study used to investigate, discover, describe, and explain the qualities or features of social influence that can not be explained, measured, or illustrated by quantitative approach. Researchers choose qualitative form because it is considered in accordance with the problem to be studied that is describing the ideology that is reflected in the discourse of Tempo Magazine in 2017 with the focus of study of text structure, social connection, and social context.

\section{Data Sources and Research Data}

Sources of data in this study are the statement of a person or journalist who poured in Tempo Magazine published on March 27, 2017, until April 16,2017 , which is believed to contain the ideology of the author, the speaker viewed from aspects of text, social connections, and social context. Discourse topics analyzed "Fireback Corruption KTP" in Tempo Magazine ".

\section{Research Data}

The data in this study are words, phrases, sentences, paragraphs that are statements of a person, a journalist's statement set forth in Tempo Magazine published March 27, 2017, to April 16, 2017. A person's statement or statement of journalists believed to contain the author's ideology, aspects of text, social connections, and social context.

\section{E. Collection Techniques and Data Collection Tools} 1. Data collection technique

The technique used in this research is indirect technique in the form of document analysis. The Tempo Magazine document published on March 27, 2017, to April 16, 2017, which is believed to contain the author's ideology, the speaker is seen from aspects of text, social connections, and social context. The data collection steps are as follows:

(a) Read critically and repeatedly Tempo Magazine,

(b) Classifying data based on research focus ie aspects of text, social connections, and social context,

(c) Discuss research data with fellow researchers.

2. Data Collector Tool

The tools used for data collection are researchers and colleagues. Researchers and associates as key instruments. Researchers as key instruments are positioned as planners, implementers, interpreters of research data, and analyzers. In addition to researchers as instruments, data collection tools used in the form of notes containing the results of reading and analyzing the discourse Tempo Magazine which is believed to contain the author's ideology, the speaker viewed from aspects of text, social connections, and social context.

F. Data Analysis Technique

Data analysis technique is a way used by writer to analyze data. The data analysis technique used in this research is based on data analysis steps proposed by Milles and Huberman (1992: 19) 
adapted to this research approach that is critical discourse analysis, that is data reduction, data presentation, and conclusion/verification as something interwoven before, during, and after the collection of data in parallel form, to build a common insight called "analysis".

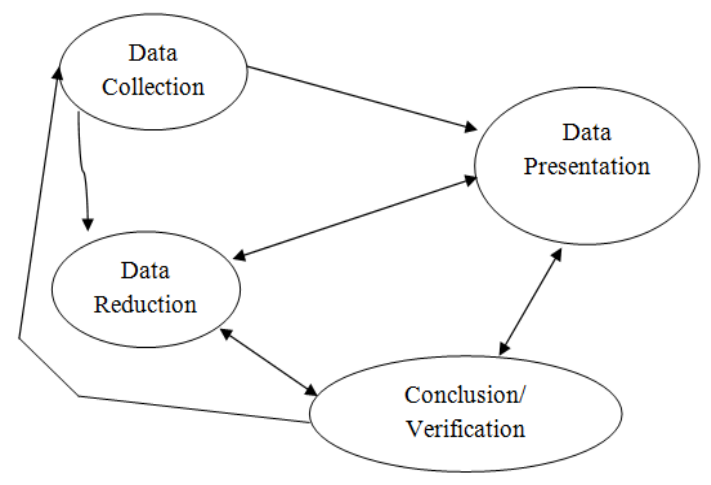

\section{RESULTS AND DISCUSSION}

\section{A. Text Structure Analysis}

\section{Macro Structure}

Topic written entitled "Fires of Corruption KTP" published in Tempo Magazine, dated April 2, 2017, page 36. This title is interesting because of the unfolding of corruption cases of electronic KTP. At the beginning of the paragraph is written: Hanura Politics which became the key KPK reveals the corruption of electronic KTP withdraw the testimony. Depressed after disclosing deployment bribe (Tempo, 2017: 36). This paragraph is the key to the discussion on this topic. Why be the key? This topic is put forward by journalists. The figure of a captured Hanura politician opens the chronological process of determination and who is involved. No half-hearted member of the board involved as many as 62 . Members of the board were bribed to pave the project worth 5.9 trillion in the year 2010-2012. Read on (Tempo, 2017: 36).

Who is the Hanura politics in question? The politics were named Miryam. He is a key figure in the case of mega corruption e-KTPs that harm the state. Miryam recounts who was involved in the case of E-KTP. Miryam told reporters that he had been asked by Setya Novanto in the office of the House Speaker on the third floor. Setya Novanto protested Miryam's testimony which confirmed there was a distribution of corruption bribes of KTP electronic to members of the Government Commission. Sentences that journalists use to describe in the form of news sentences. The news was followed by strong evidence. The mention of the name "Sugiharto" proves the confidence of information obtained by journalists is believed to be true. Check out the following sentence. "As Sugiharto admitted to the Corruption Eradication Commission investigator, he once gave Rp4 billion to Mark in March 2012 at
Bebek Bali Senayan Restaurant, South Jakarta (Tempo, 2017: 36).

Fireback corruption KTP addressed to Setya Novanto. Why is KTP corruption bolt fixed on Setya Novanto? The journalist believes Setya Novanto is involved. Journalists describe it in this topic. With his assignment mention, Setya Novanto related in case of mega corruption e-KTP. The journalist explicitly explained what Setya Novanto has done. Reporters believe Setya Novanto maneuvered to defend or secure himself. Setya Novanto met with politicians whose names were mentioned in the indictment of mega corruption. The use of the phrase "Secretly Setya Novanto guerrillas meet the politicians of the House of Representatives whose name is mentioned in the indictment of mega corruption". With the choice of the word "secretly" means Setya Novanto take action to know and regardless of his involvement in the case of mega corruption e-KTP. The action he did secretly and in guerrilla. Can be read (Tempo: 2017: 36).

Journalists dare to use the phrase and choice of words that "dare". Why is it bold? Journalists use the word "guerrillas". The meaning of guerrillas is to perform an action in a structured and stealthy manner. Why choose the word "guerrilla". Its meaning is negative. In this sentence, the word "guerrilla" takes action to know "something" in order to cover "something". The sentence becomes negative because it begins with the word "stealth". Sentences that journalists use to describe this news with a straightforward sentence. Why is it said straightforwardly? This discourse is expressed by journalists based on interviews from various sources and the coverage of Tempo reporters. The courage of the Tempo journalist deserves a thumbs-up. They dared to mention the names of the characters involved. Like the first paragraph: Secretly Setya Novanto guerrillas meet the politicians of the House of Representatives whose name is mentioned in the indictment of the procurement of electronic identity Card (e-KTP) in the Ministry of Interior. One of them Markus Nari, his men in Golkar Party ".

2. Superstructure

The topic of "Fireback of Corruption KTP" was arranged systematically by Tempo reporters. The sections in this topic are structured to form an interesting story. The ability of journalists to describe the events and compiled into an interesting news. By using the title "Fireback Corruption KTP" meaning fireball is already crawling. Fireball ball is hot. The hot bulb of the mega corruption case is already racking towards the people involved in the case of mega corruption e-KTP.

In the preliminary part of the discourse, the first paragraph, the journalist describes the behavior of a famous party figure, Setya Novanto. This figure is described secretly to do guerrilla to meet the politicians involved in the case of electronic KTP. 
The second paragraph is a preliminary part of this discourse. Why? The second paragraph describes the figure of Setya Novanto's men listed in the indictment for Irman and Sugiharto. They are two officials in the Interior Ministry who are accused of bribing 62 members of the House of Representatives to smooth the project worth Rp. 5.9 trillion in 20102012. Recognition Sugiharto once gave money of Rp 4 billion to Markus Nari in March 2012, at Bebek Bali Senayan Restaurant, South Jakarta. Based on this paragraph it is related to the next few paragraphs that become the contents of the discourse entitled "Fireburn Corruption KTP".

Andi Narogong was arrested and named suspect by the KPK. Paragraph twenty describes the resignation of Setya Novanto. He shook his head when asked for confirmation about his attempts to influence e-KTP corruption witness. He told reporters on Monday last week that he hoped there would be no intervention regarding the e-KTP trial. "Just be in court," he said (Read Tempo, 2017: 37, P.20).

3. Microstructure

Based on the analysis that focuses on the microstructure of a discourse, it can be seen from several meanings to be conveyed by journalists through the discourse written entitled "Fire Balls Corruption KTP". The meaning is related to the content of the discourse. First. Corruption balls are fixed on Setya Novanto and members of DPR. In chronology, the figure of Markus Nari who is a subordinate Setya Novanto described journalists are instrumental in e-KTP corruption. Markus Nari's name is contained in the indictment for Irman and Sugiharto, two officials in the Interior Ministry who are accused of bribing 62 members of the House to smooth the project worth Rp. 5.9 trillion in 20102012. Sugiharto claimed to have given Rp 4 billion to Markus Nari in March 2012 at Bebek Bali Senayan Restaurant in South Jakarta.

Second. Markus Nari has also led Miryam S Haryani, the Hanura policeman, met with his fellow Golkar politicians. They talked about the problem of mega corruption that dragged many well-known politicians in Senayan. To the politician, Miryam told that she had been asked by Setya Novanto in the Working Room of DPR Chairman on the third floor of DPR building.

Third. Miryam is the main node of Irman and Sigiharto charges. To the KPK, he claimed to have asked him if given "something" by other members of the Commission. Chairuman, Mirya said to the investigator, asking all the money to be put into an envelope to be shared with other colleagues in Commission III. The money was distributed to the chairman and Chairman of the Faction Group Miryam.

Fourth. The role of Andi Narogong in mega corruption e-KTP. Setya Novanto several times met the Interior Ministry officials with intermediary Andi
Narogong. Setya Novanto and Andi Narogong appeared his name in the procurement project of Rp. 400 billion in the troubled Interior Ministry. Andi Narogong also recommended Irman to be the Director General of Population Administration and he is also expected to smooth the e-KTP project. The evidence was revealed by Irman claimed to have met Andi to set the KTP.

\section{B. Social Cognition Analysis}

This discourse is very attractive to the people of Indonesia. The discourse associated with mega corruption of e-KTP is very busy discussed in the mass media, such as TV, newspapers, and magazines. Proven that news of this case more crowded because many are involved and until now has not been completed. The journalist's view of the megacorruption case and the journalist's strategy presented him to be warmer.

The discourse presented by journalists is not only a mere text but provides a complex picture and representation and strategy used in producing a text. The journalist's confidence in the news presented with strong evidence will be interesting and the reader becomes confident in the information the reporter submits.

The discourse entitled "Fireball Corruption KTP" is far away. The ball has reached the House of Representatives building. Not only board members are allegedly involved in this case, but the chairman of the House is also suspected of involvement in this case of mega corruption of e-KTP. The persistence of journalists in search of data supporting this title proves journalists' confidence in the case. The data that have been obtained from sources believed to be true then analyzed and cross-checked with other sources. If there is no conflict, then this news "Fireback Corruption KTP" can be analyzed.

Presentation at the beginning of this discourse begins with "Hanura politician who became the key KPK reveals corruption of electronic KTP withdraw the testimony. Distinct after disclosing the spread of bribes ". Statement by journalists regardless of the title discourse.

This news is interesting because many are involved. The people allegedly involved members of the House of Representatives and Chairman of the House of Representatives as well as Chairman of the Golkar Party. The courage of journalists in listing the names of members of DPR and House Speaker shows the Tempo journalists' confidence with the data they get.

The way the reporter presents this news is great. Sentences are used using effective sentences and have a causal relationship. Readers will easily understand the purpose of sentences exposed by journalists. The information collected is stored in its memory and integrated with new information describing how the incident of e-KTP corruption is 
understood, interpreted, and included as part of the journalist's knowledge.

\section{Social Context Analysis}

This analysis focuses on intertextual analysis by examining how discourses about things are produced and constructed in society. Our concern is indispensable for really analyzing "power". An important point of this analysis is to show how shared meanings, social power are produced through the practice of discourse and legitimacy. This analysis is seen from two sides, namely (1) power, (2) access. Both sides according to van Dijk are very important.

1. Practice of Power

The discourse entitled "Fire Balls of Corruption KTP" can be reviewed based on power practice. Disclosure of the statement of the suspect is Sugiharto. He is an official in the Interior Ministry. He was accused of bribing members of the House of Representatives as many as 62 people. This is done so that the project worth Rp. 5.9 trillion in the year 2010-2012 it runs. Sugiharto claimed to have given the money through Mark. Why can Sugiharto give that kind of money? Sugiarto was then an official at the Ministry of Home Affairs conducting an e-KTP program. His desire for the E-KTP program can be approved. (Read Tempo, 2017: 36. P 2).

The following power practice in this discourse is the figure of Setya Novanto. Why use his power? Why should he do his power? Setya Novanto is a figure of Head of Golangan Karya Party and Chairman of DPR RI. Miryam had visited the Setya Novanto workshop. Setya Novanto protested Miryam's testimony that confirms there is a share of E-KTP corruption money. As a Chairman of the House of Representatives whose name is called receiving a bribe case of mega corruption KTP in the testimony of Miryam would feel disturbed. By using his position as Chairman of the House of Representatives, he called Miryam in his office. He tried not to get involved. Check out the following quote. (Tempo, 2017: 36, P. 8).

2. Access Side Analysis

This access analysis focuses on access to convey or influence speech or reader partners. In the discourse entitled "Fireback Corruption KTP" found the access side used by persons who allegedly involved in mega corruption KTP. Access has used in a variety of ways. Setya Novanto's figure used the opportunity to dialogue with his colleagues. During last year's Golkar party event. Setya Novanto asked the involvement of his colleagues in the case of mega corruption. Setya Novanto colleagues who were asked related to his involvement, in this case, is Mark. (Tempo, 2017: 36, P.3).

The use of subsequent access in this discourse is Sugiharto. Sugiharto is a member of the Ministry of Home Affairs who allegedly involved or enjoyed the mega corruption of KTP. He took advantage of his position to find the money used to bribe members of the House of Representatives. Sugiharto received funding from PT Quadra Solution, a member of the Consortium of State Printing of the Republic of Indonesia. This PT is the winner of this project tender. (Tempo, 2017: 26, P.4).

\section{CONCLUSION}

Based on the results of data analysis, it can be concluded as follows.

1. Viewed from the text structure of this discourse, journalists dare to reveal the case. "Fire corruption KTP" is located on Setya Novanto. This figure is described secretly to do guerrilla to meet the politicians involved in the case of electronic KTP. This is described in this discourse because Miryam tells anyone who is involved in the case of e-KTP. This becomes the umbrella of this discourse. Sentences of news, straightforward sentences supported by strong evidence used by journalists to describe anyone involved.

2. Judging from social cognition the text of this discourse is far away. The ball has reached the House of Representatives building. Not only board members are allegedly involved in this case, but the chairman of the House is also suspected of involvement in this case of mega corruption of e-KTP. The persistence of journalists in search of data supporting this title proves journalists' confidence in the case. The data that have been obtained from sources believed to be true then analyzed and crosschecked with other sources. If there is no conflict, then this news "Fireback Corruption KTP " can be analyzed.

3. Viewed from the social context of this discourse is examined through power practices and access side analysis. Judging from the practice of his power explained officials who play a role in corruption KTP cases. The official is Sugiharto who served in the Ministry of Interior and Setya Novanto is a famous Party Chairman and Chairman of the House of Representatives. They both use access as an official.

\section{REFERENCES}

Darma, Yoce Aliah. 2009. Analisis Wacana Kritis. Bandung: Yrama Widya.

Eriyanto. 2001. Analisis Wacana Pengantar Analisis Teks Media. Yogyakarta: LkiS.

Fairclough, Norman.1989. Language and Power: Relasi Bahasa, Kekuasaan dan Ideologi. Penerjemah: Indah Rohmani.

Faircough, Norman. (ed.). 1995. Critical Language Awareness. Penerjemah: Hartoyo. Semarang:IKIP Semarang.

Fairclough, Norman, (ed.). 1992. Perspective and Ideology in Language. Penerjemah:Hartoyo. Semarang: IKIP Semarang. 
Foucault, Michel. 1971. Kritik Wacana Bahasa. Penerjemah: Inyiak Ridwan Muzir. Yogyakarta: IRCiSoD.

Jorgensen, Marianne W and Louise J Phillips. 2010. Analisis Wacana: Teori \& Metode. Penerjemah: Imam Suyitno, Lilik Wahyuni, Suwarna. Yogyakarta: Pustaka Pelajar.

Miles, Matthew B dan A. Michael Huberman, 1992. Analisis Data Kualitatif : Buku Sumber Tentang Metode-Metode Baru. Penerjemah: Tjetjep Rohendi Rohidi. Jakarta: UI-Press.

Poespoprodjo. 1987. Interpretasi. Bandung: Remadja Karya.

Samsuri, 1994. Analisis Bahasa. Jakarta: Penerbit Erlangga.

Sobur, Alex. 2002. Analisis Teks Media. Suatu Pengantar untuk Analisis Wacana, Analisis Semiotik, dan Analisis Framing. Bandung. PT. Remaja Rosdakarya.

Sobur, Alex. 2003. Semiotika Komunikasi. Bandung: PT Remaja Rosdakarya.

Spradley, James P. 1997. Metode Etnografi. Penerjemah Misbah Zulfa Elitzabeth. Yogyakarta: Tiara Wacana.

Sudibyo, Agus. 2001. Politik Media dan Pertarungan Wacana. Yogyakarta: LkiS.

Tempo, 27 Maret - 2 April 2017. “Awas Kredit Macet" Jakarta

Tempo, 3 - 9 April 2017. “KPP Gawat” Jakarta.

Tempo, 10 - 16 April 2017. "Siti Aisyah dan Pembunuhan KIM JONG -NAM". Jakarta.

Thomson, John B. 1984. Analisis Ideologi: Kritik Wacana Ideologi-Ideologi Dunia. Penerjemah: Haqqul Yaqin. Yogyakarta: IRCiSoD.

Thompson, John B. 1990. Kritik Ideologi Global Teori Sosial Kritis tentang Relasi Ideologi dan Komunikasi Massa. Penerjemah. Haqqul Yaqin. Yogyakarta: IRCiSoD.

Titscher, Stefan, Michael Mayer, dkk. 2009. Metode Analisis Teks dan Wacana. Penerjemah: Gazali dkk. Yogyakarta: Pustaka Pelajar. 